\title{
Tannery Wastewater Treatment Using Low Cost Coagulants with Simple Coagulation- Filtration Process
}

\author{
Bishnu Chandra Barman, Md. Ariful Islam Juel", Md. Abul Hashem
}

Department of Leather Engineering, Khulna University of Engineering \& Technology (KUET), BANGLADESH

*Corresponding Contact:

Email: juel_islam@le.kuet.ac.bd

\begin{abstract}
Tannery is the oldest industries in the world. It is characterized as pollutants generating industries, which produce wide varieties of high strength toxic residues. This study has been focused on the removal of physicochemical parameters of tannery wastewater through simple coagulation-filtration techniques using low cost coagulants. Standard methods were used for sampling and analysis. Removal efficiency was measured in terms of reduction of COD, BOD5, suspended solids (SS), total dissolved solids (TDS), conductivity and color. Several doses of coagulants e.g. alum, ferric chloride and their combination were used in treatment process. Maximum removal efficiency was obtained with the combination of alum and ferric chloride dosing at $75 \mathrm{mg} / \mathrm{L}$ in terms of color, BOD5, COD, TDS, SS and conductivity corresponding to $75 \%, 78 \%, 76 \%, 37 \%$, $94 \%$ and $41 \%$ respectively and that were increased to $92 \%, 82 \%, 80 \%, 48 \%, 98 \%$ and $51 \%$ respectively after sand-stone filtration. Ferric chloride and combination of alum and ferric chloride are recommended for the effective primary treatment of tannery wastewater. The filtration with multi-layer sand-stone filter was effective in removing of color, TDS, conductivity and SS.
\end{abstract}

Key words

Tannery wastewater, Suspended solids, Alum, Ferric chloride, Coagulants, COD, BOD

\section{INTRODUCTION}

Tannery is one of the oldest industries in the world. It is typically characterized as pollutants generated industries, which produce wide varieties of high strength toxic residues. It is recognized as a serious environmental threat due to high chemical levels including salinity, conductivity, chemical oxygen demand (COD), biological oxygen demand (BOD), inorganic matter, suspended solids (SS), total dissolved solids (TDS), and heavy metals etc. (Apte et al. 
2005; Tariq et al. 2005; Chaudry et al. 1998). Tannery effluent affects the receiving water quality in multiple ways. The discharged biodegradable organic compound causes a strong reduction of dissolved oxygen (DO) in the surface water. Macronutrients such as phosphorus and nitrogen may cause eutrophication of the receiving aquatic bodies. Tannery effluent contains compound e.g. chromium $(\mathrm{Cr})$ and unionized ammonia which are toxic to aquatic life (Shegani, 2014). In leather processing large amount of water is used, of which $90 \%$ is discharged as effluent van (Groenestijn et al., 2002). During chrome tanning, $60 \%$ of the chromium salt is taken up by the pelt and the rest of $40 \%$ chromium is usually discharged in the final effluent, causing a serious threat to the environment (Leghouichi et al. 2009; Owlad et al. 2009; van Groenestijn et al. 2002).

In Bangladesh, there are 160 tanneries among them 155 are located at Savar tannery village, about 24 kilometers to the northwest of Dhaka city where daily about $20000 \mathrm{~m}^{3}$ of liquid waste is discharged from all the tanneries which contains $180 \mathrm{mg} / \mathrm{L}$ of chromium (Shams et al. 2009). All the tanneries are connected to the central effluent treatment plant (CETP). Though the CETP was supposed to treat the whole wastewater efficiently through chemical, biological and tertiary treatment system, at present only 2 out of 4 module of biological treatment system is operational and treat a small part of the total wastewater and even treated effluent is poor in quality and do not comply the discharge standards of Bangladesh (ECR 1997). These untreated and partially treated wastewater have been directly discharged to the nearby Dhaleswari river and get polluted. Exposure to chromium, pentachlorophenol and other toxic pollutants increase the risk of dermatitis, ulcer, nasal septum perforation and lung cancer (Komhauser et al., 2002). Therefore, treatment of tannery waste water has become a prime requisite for the tanning industry.

A number of researchers reported on the tannery wastewater treatment with different techniques, such as flotation, electrochemical treatment, sedimentation, coagulation, filtration, ultra-filtration and reverse osmosis process (Song et al. 2003; Ates et al. 1997). Coagulationflocculation is the second stage of coagulation process which has two distinct processes usually carried out in the combination of physical and chemical procedures during primary treatment of tannery wastewater. The most commonly used coagulants for the treatment of tannery wastewater are: commercial aluminum sulfate $\left(\mathrm{Al}_{2}\left(\mathrm{SO}_{4}\right) 3.18 \mathrm{H}_{2} \mathrm{O}\right)$, commercial iron sulfate $\left(\mathrm{FeSO}_{4} .7 \mathrm{H}_{2} \mathrm{O}\right)$, commercial ferric chloride $\left(\mathrm{FeCl}_{3} .6 \mathrm{H}_{2} \mathrm{O}\right)$, and lime $(\mathrm{CaO})$ (Genovese et al. 1998).

Wastewater treatment techniques depend on several factors like efficiency, cost-effective and environmental capability (Costa et al. 2009). So far only a few researchers have been reported on chemical treatment of tannery wastewater in Bangladesh (Hashem et al., 2016; Imran et al., 2012; Haydar et al., 2009; Song et al., 2004; Dantas et al., 2003). All the researchers have used analytical grade coagulants in their studies. So far Sabur et al., (2013) have investigated the tannery effluents with the commercial grade lime as coagulant.

In this study, an attempt was made to treat the tannery wastewater by low cost coagulants especially commercial grade alum and ferric chloride to find out their removal efficiency with simple coagulation-filtration process.

\section{MATERIALS AND METHODS}

\section{Sampling}

Tannery wastewater was collected from the SAF Leather Industries Ltd., Khulna, Bangladesh. The wastewater sample was the mixture of all stages of tanning process e.g. soaking, liming, deliming, bating, pickling, chrome tanning and retaining. The wastewater was collected in the 
plastic bottles which were pre-washed with dilute nitric acid solution followed by repeatedly washing with distilled water then dried overnight and marked corresponding identification numbers. The samples were brought to the laboratory with due care for experiment. After collection, physical appearance and temperature of the samples were recorded and $1.5 \mathrm{~mL}$ concentrated nitric acid per liter of sample was added as preservative.

\section{Reagents}

The reagents mercury (II) sulfate (Darmstadt, Germany), potassium dichromate (K2Cr2O7) (Coinbrook Berks, England), silver sulfate (Merck, Germany), ferrous ammonium sulfate (LobaChemie, India), sulfuric acid were purchased from the local scientific store. The low cost coagulants: alum, ferric chloride, and lime were purchased from the local market.

\section{Treatment process}

Tannery wastewater was examined batch wise through coagulation-filtration process using alum $\left(\mathrm{Al}_{2}\left(\mathrm{SO}_{4}\right)_{2}\right)$ and ferric chloride $\left(\mathrm{FeCl}_{3}\right)$ as coagulants. Each batch 1-liter tannery wastewater was treated with different coagulants doses (20 to $200 \mathrm{mg} / \mathrm{L}$ ). After adding coagulant, mixture was stirred for 15 minutes and allowed to rest for 24 hours. Batch wise coagulation process was conducted at the $\mathrm{pH} 5.0,6.0,7.0,8.0,9.0$ and 10.0. In the treatment process, $\mathrm{pH}$ was adjusted with diluted hydrochloric acid $(\mathrm{HCl})$ and lime solution. Then supernatant was filtered through three layer filter beds, which were designed as a stone ( $\leq 5 \mathrm{~mm}$ diameter) at the top, coarse sands (1 $\mathrm{mm}$ diameter) at the middle and fine sands ( $\leq 0.15 \mathrm{~mm}$ diameter) at the bottom. Each filter bed layer widths were $10-12 \mathrm{~cm}$. The physicochemical parameters of the filtrate were analyzed. The physicochemical parameters e.g. pH, SS, TDS, conductivity, BOD, COD and color of the supernatant was measured.

\section{Determination of physiochemical parameters}

The physicochemical parameters of the raw wastewater and chemically treated filtrate were analyzed. Total dissolved solids (TDS) and total suspended solids (TSS) were determined gravimetrically followed by the standard APHA (APHA, 2012) method. A $50 \mathrm{~mL}$ sample was dried at drying oven at $103 \pm 2{ }^{\circ} \mathrm{C}$ until a constant weight was obtained. $\mathrm{pH}$ was measured by the $\mathrm{pH}$ meter (UPH-314, UNILAB, USA). Electrical conductivity (EC) and TDS was measured using the conductivity meter (CT-676, BOECO, Germany). Before measuring all the parameters, meters were calibrated with the standard solutions.

Measurement of BOD 5 : A $300 \mathrm{~mL}$ water sample was taken in dissolved oxygen (DO) bottle and DO was measured with DO meter (DO meter-40D, HACH, USA). The DO bottle was kept in the incubator for five days and again DO was measured. The cumulative $\mathrm{DO}$ was calculated by the subtraction of the initial DO value and after incubation of DO value.

Determination of COD: Raw sample and chemically treated filtrate COD was determined by the titrimetric method with ammonium iron (II) sulfate $\left[\left(\mathrm{NH}_{4}\right)_{2} \mathrm{Fe}\left(\mathrm{SO}_{4}\right)_{2} \cdot 6 \mathrm{H}_{2} \mathrm{O}\right]$ and ferroinas indicator until the color changes from blue-green to red-brown.

\section{RESULTS AND Discussion}

\section{Optimization of coagulants}

Fig. 1 represents the effect of coagulants doses on the removal efficiency of the suspended solids (SS). The maximum removal of $\mathrm{SS}$ was $95 \%$ for $200 \mathrm{mg} / \mathrm{L}$ at $\mathrm{Al}_{2}\left(\mathrm{SO}_{4}\right)_{3}$ (alum) dosing. The removal percentage of SS was gradually increased with alum dosing up to $200 \mathrm{mg} / \mathrm{L}$ then decreased. $\mathrm{Al}_{2}\left(\mathrm{SO}_{4}\right)_{3}$ is dissolved in water and produce sulfate anoins $\left(\mathrm{SO}_{4}{ }^{2-}\right)$ and aluminum cations $\left(\mathrm{Al}^{3+}\right)$. The $\mathrm{Al}^{3+}$ cations react with water to form aquometallic ions and 
hydrogen. As they have a great affinity for surface, are adsorbed onto the surface of the colloid where they neutralize the surface charge. Once the surface charge has been neutralized, the ionic cloud dissipates and the electronic potential disappears so that contact occurs freely and form flocs. This was happened upto $200 \mathrm{mg} / \mathrm{L}$ alum dosing for which highest SS removal obtained. However, after this point, SS removal was decreased as the overdosing of alum could result in restabilizing the suspension due to charge reversal on the particles (Peavy et al. 1985).

In case of $\mathrm{FeCl}_{3}$ (ferric chloride), the maximum removal of SS was $89 \%$ with $150 \mathrm{mg} / \mathrm{L} \mathrm{FeCl3}$ dosing whereas in combination, the maximum removal of SS was $90 \%$ with only $75 \mathrm{mg} / \mathrm{L}$ dosing. Similar incident like alum dosing happened for both ferric chloride and the combination of alum and ferric chloride when coagulant dosing had been passed the optimum level. This incident was explained differently by Islam et al. (2011) that when coagulant dose was very high, wastewater particles were surrounded by a large quantity of coagulant particles as a result their surfaces were saturated resulting less possibility to combine with each other therefore reached another state of stability.

It was observed that neutralizing power of different coagulants on particle surface was different and the dosing combination of alum and ferric chloride efficiently removed the highest percentage of SS at comparatively lower dose than individual coagulant doses.

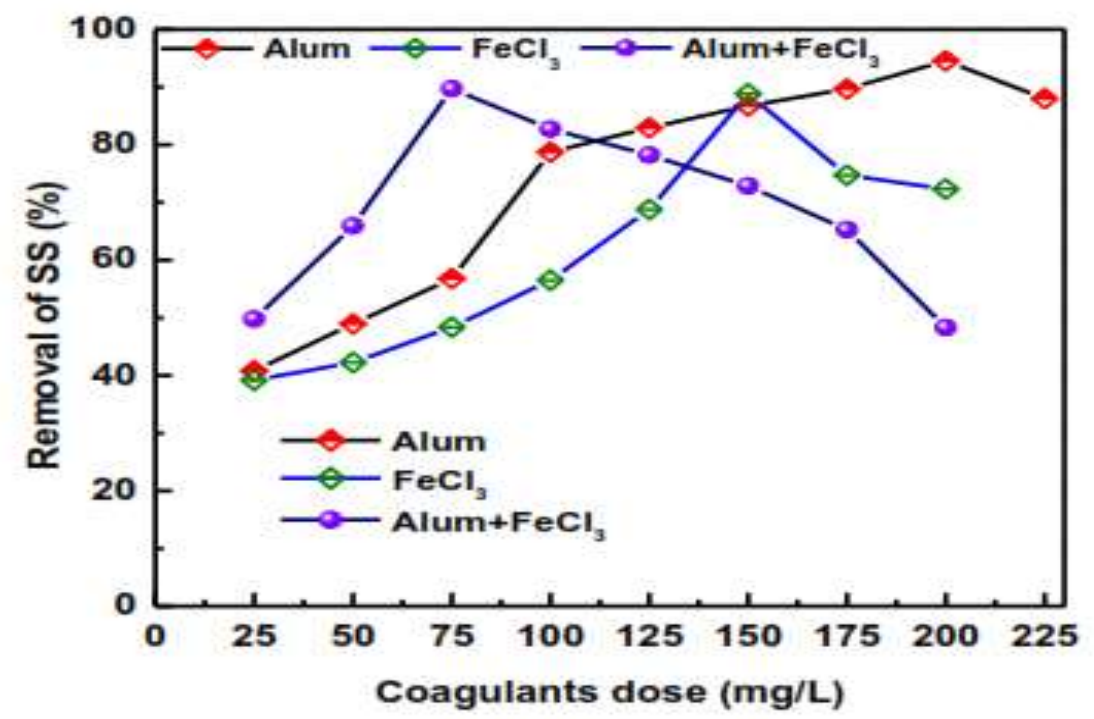

Fig. 1: The effect of coagulants doses $(\mathrm{mg} / \mathrm{L})$ on the removal $(\%)$ of $\mathrm{SS}$ at $\mathrm{pH} 7$

\section{Effect of $\mathrm{pH}$ on coagulation}

Effect of $\mathrm{pH}$ on coagulant dose with $120 \mathrm{mg} / \mathrm{L}\left(\mathrm{Al}_{2}\left(\mathrm{SO}_{4}\right)_{3}\right)$ is shown in Fig. 2. It is clear from the Fig. 2 that with increasing $\mathrm{pH}$ removal percentage of SS was increased until $\mathrm{pH} 8.0$ then decreased where the maximum removal of SS obtained $93 \%$. It is noted that $\mathrm{pH}$ has an important role in the coagulation process which controls the hydrolysis species (Kim et al. 2001).At $\mathrm{pH} 8.0$, conductivity and TDS were removed $31 \%$ and $35 \%$. However, removal efficiency for conductivity and TDS was not good. Although at $\mathrm{pH} 9.0$, the maximum removal of TDS and conductivity were obtained and they were $36 \%$ and $39 \%$, respectively. 


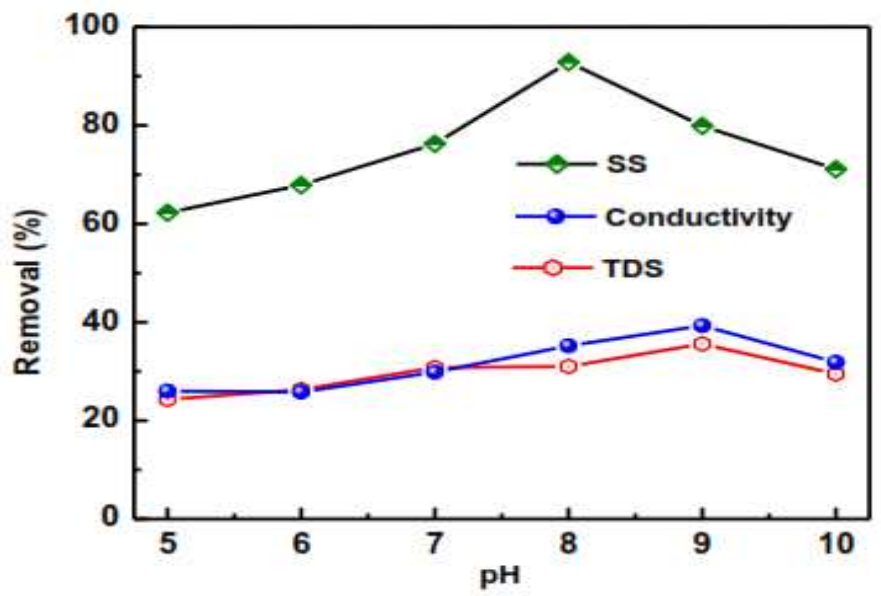

Fig. 2: Effect of $\mathrm{pH}$ on coagulation process

Effect of $\mathrm{pH}$ on the coagulant dose with $150 \mathrm{mg} / \mathrm{L} \mathrm{FeCl}_{3}$ is shown in Fig. 3. The maximum removal efficiencies e.g. SS, conductivity and TDS were found at $\mathrm{pH} 8.0$ and then gradually reduced on the both sides. The maximum removal for SS, conductivity and TDS were 91\%, $17 \%$ and $20 \%$, respectively. The colloid substances from tannery effluents usually carry negative electrical charges, whereas coagulant $\left(\mathrm{FeCl}_{3}\right)$ possesses a lot of cation (Fe3+) ions. Near neutral ( $\mathrm{pH} 8.0$ ), Fe(III) hydrolyzes into mononuclear and multi nuclear hydroxyl complex ions, which have the potentially to adsorb particles and form electric double layer for the destabilization of the particles (Islam et al. 2011). The study attributes from the results that $\mathrm{pH}$ has a great influence on coagulation process in removing different parameters from the tannery wastewater. However better removal efficiency were found at wider $\mathrm{pH}$ range (7-9) in case of ferric chloride compared to alum.

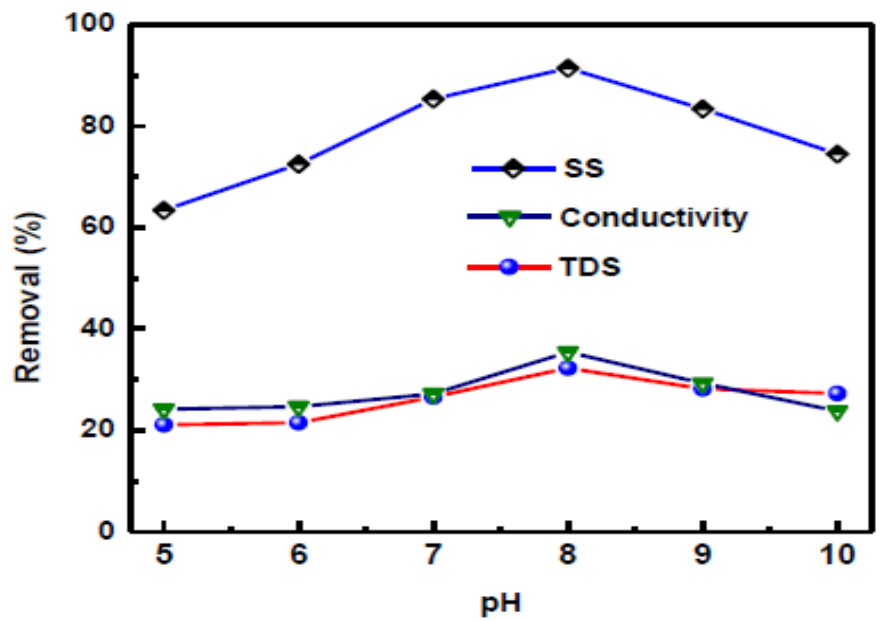

Fig. 3: Effect of $\mathrm{pH}$ on coagulant dose at $\mathrm{FeCl} 3$ of $175 \mathrm{mg} / \mathrm{L}$

\section{$\mathrm{pH}$ and color}

The average $\mathrm{pH}$ of the raw wastewater from the tannery was 10.6 which were reduced to 6.9, 7.3 and 7.2 after treatment process with $\mathrm{Al}_{2}\left(\mathrm{SO}_{4}\right)_{3}, \mathrm{FeCl}_{3}$ and combination of $\mathrm{Al}_{2}\left(\mathrm{SO}_{4}\right)_{3}$ and $\mathrm{FeCl}_{3}$, respectively. Sepehr et al. (2005) reported that $\mathrm{pH}$ of the tannery waste water as 
3.0 to 3.5 , which was a very acidic condition. (Krishanamoorthi et al. 2009) observed that pH of the tannery wastewater as 8.0 to 9.0. The average color range of the raw wastewater was $700 \mathrm{Pt}-\mathrm{Co}$ units which were about 47 times higher than the recommended value $(15 \mathrm{Pt}-\mathrm{Co}$ units). The color appearance of raw wastewater was found black. The analysis results indicate that the raw wastewater contained highly colored compound which has the potentially to pollute the environment. The original color of the wastewater $(700 \mathrm{Pt}-\mathrm{Co}$ units) was reduced to $17 \mathrm{Pt}-\mathrm{Co}$ units after $\mathrm{Al}_{2}\left(\mathrm{SO}_{4}\right)_{3}$ coagulation followed by sand-stone filtration. The removal efficiency was $79 \%$ that was increased to $97 \%$ after filtration with sand-stone filter. The removal efficiency of ferric chloride and combination of $\mathrm{Al}_{2}\left(\mathrm{SO}_{4}\right)_{3}$ and $\mathrm{FeCl}_{3}$ followed by filtration were $87 \%$ and $91 \%$, respectively.

\section{$\mathrm{BOD}_{5}$ and $\mathrm{COD}$}

The average values for $\mathrm{BOD}_{5}$ and $\mathrm{COD}$ of the raw wastewater from the tannery were 7600 $\mathrm{mg} / \mathrm{L}$ and $22400 \mathrm{mg} / \mathrm{L}$ respectively (Table 1). The dirt, decomposed hair keratin, globular protein, non-collagen protein, residual proteolytic enzymatic agents and residual chemicals in the tanning process are responsible for high BOD and COD. High BOD of raw wastewater indicates high organic pollution, which will gradually reduce the dissolved oxygen creating unfavorable condition for aquatic lives (Verma et al. 2012). The physicochemical parameters after treatment process were significantly reduced with different coagulants doses.

Table 1: The physicochemical characteristics of the raw wastewater from the tannery and after treatment

\begin{tabular}{|c|c|c|c|c|c|c|c|c|}
\hline \multirow[b]{2}{*}{ Parameter } & \multirow[b]{2}{*}{$\begin{array}{c}\text { Raw } \\
\text { sample }\end{array}$} & \multicolumn{3}{|c|}{ After coagulation-filtration process } & \multirow{2}{*}{ 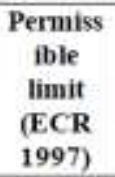 } & \multicolumn{3}{|c|}{$\begin{array}{c}\text { Removal efficiency } \\
(\%)\end{array}$} \\
\hline & & $\mathrm{Al}_{2}\left(\mathrm{SO}_{4}\right)_{3}$ & $\mathrm{FeCl}_{3}$ & $\begin{array}{l}\mathrm{Al}_{2}\left(\mathrm{SO}_{4}\right)_{3} \\
+\mathrm{FeCl}_{3}\end{array}$ & & \begin{tabular}{|c|}
$\mathrm{Al}_{2}$ \\
(SO \\
$4)_{3}$
\end{tabular} & $\mathrm{FeCl}_{3}$ & $\begin{array}{c}\mathrm{Al}_{2}\left(\mathrm{SO}_{4}\right)_{3} \\
+\mathrm{FeCl}_{3}\end{array}$ \\
\hline $\mathrm{pH}$ & $10.5 \pm 0.03$ & $6.91 \pm 0.21$ & $7.3 \pm 0.19$ & $7.2 \pm 0.02$ & $6-9$ & & & \\
\hline $\begin{array}{l}\text { Color } \\
\text { (pt./co) }\end{array}$ & $699 \pm 2.35$ & $19.04 \pm 2.45$ & $90 \pm 3.15$ & $60 \pm 3.50$ & 15 & 97 & 87 & 91 \\
\hline $\begin{array}{l}\text { BOD } \\
(\mathrm{mgL})\end{array}$ & $7600 \pm 8.65$ & $1595 \pm 4.45$ & $1669 \pm 6.32$ & $1404 \pm 6.89$ & 50 & 79 & 78 & 82 \\
\hline $\begin{array}{l}\mathrm{COD} \\
(\mathrm{mg} / \mathrm{L})\end{array}$ & $\begin{array}{c}22399 \pm 11 \\
7\end{array}$ & $5833 \pm 8.32$ & $5267 \pm 6.42$ & $4514.6 \pm 5.62$ & 200 & 74 & 76 & 80 \\
\hline $\begin{array}{c}\text { TDS } \\
(\mathrm{mg} / \mathrm{L})\end{array}$ & $\begin{array}{c}27589 \pm 9.0 \\
3\end{array}$ & $14694 \pm 6.56$ & $15119 \pm 4.04$ & $14569 \pm 3.72$ & 2100 & 47 & 45 & 47 \\
\hline SS (mg/L) & $\begin{array}{c}13050 \pm 11 \\
6\end{array}$ & $711 \pm 3.45$ & $210.01 \pm 2.53$ & $275.03 \pm 3.07$ & 150 & 95 & 98 & 98 \\
\hline $\begin{array}{l}\text { Conductivit } \\
y \text { (mS) }\end{array}$ & $49.9 \pm 1.95$ & $25,07 \pm 1.42$ & $23.94 \pm 1.23$ & $24.36 \pm 1.78$ & 1.2 & 49 & 52 & 51 \\
\hline
\end{tabular}

*ECR- Environmental Conservation Rule

The minimum $\mathrm{BOD}_{5}(1404 \mathrm{mg} / \mathrm{L})$ and $\mathrm{COD}(4515 \mathrm{mg} / \mathrm{L})$ values were found with the treatment process using the combination of $\mathrm{Al}_{2}\left(\mathrm{SO}_{4}\right)_{3}$ and $\mathrm{FeCl}_{3}$ dosing at $75 \mathrm{mg} / \mathrm{L}$ followed by filtration. The combination dose $\left.\left[\mathrm{Al}_{2}\left(\mathrm{SO}_{4}\right)_{3}+\mathrm{FeCl}_{3}\right)\right]$ at $75 \mathrm{mg} / \mathrm{L}$ showed comparatively better removal efficiency than individual coagulants for BOD5 (78\%) and COD (76\%) (Fig. 4). After filtration, efficiency was increased to $82 \%$ (BOD5) and $80 \%$ (COD), respectively (Table 1). Even at optimum doses with the coagulants, all parameters except $\mathrm{pH}$ of the treated effluent were still higher than the standard discharge limit of Bangladesh (ECR 1997). Only chemical or biological treatment method is unable to treat the tanner wastewater efficiently due complex nature of the tannery wastewater (Juel et al. 2017). 


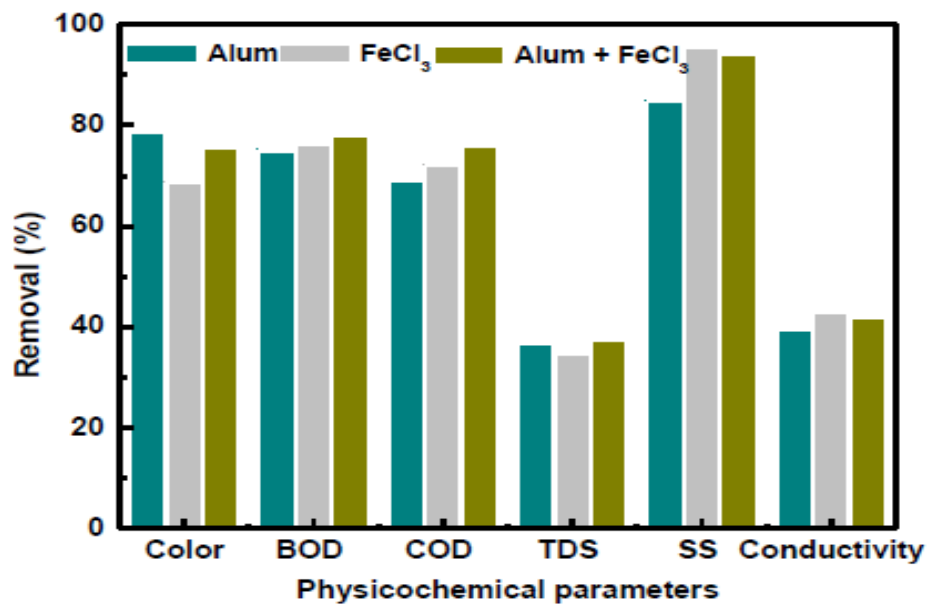

Fig. 4: Removal efficiency of physicochemical parameters with different coagulants

\section{CONCLUSION}

The study showed that the raw tannery wastewater was contained extremely high values of BOD, COD, SS, TDS and conductivity. It has been revealed that ferric chloride and combination of alum and ferric chloride was effective as coagulant for the removal of SS, BOD and COD from tannery wastewater but the combination of alum and ferric chloride requires comparatively lower doses than individual coagulants. The filtration process was very effective in removing color and suitable for removing TDS, conductivity and SS. The coagulants alum and ferric chloride were effective at $\mathrm{pH}$ 8.0.The value of all parameters was still higher than permissible level and requires further treatment. However, coagulation process with combination of alum and ferric chloride could be used as primary treatment. The filtration with multilayer sand-stone filter was very effective in removing color as well as for TDS, conductivity and SS.

\section{REFERENCES}

American Public Health Association (APHA)(2012) Standard Methods for the Examination of Water and Wastewater, 22th ed., American Public Health Association, American Water Works Association, Water Environment Federation, Washington DC, USA.

Apte AD, Verma S, Tare V, Bose $\mathrm{P}(2005)$ Oxidation of $\mathrm{Cr}(\amalg)$ in tannery sludge to $\mathrm{Cr}(\mathrm{vi})$ : Field observations and theoretical assessment. JHazard Mater 121:215-222.

Ates E, Orhon D, Tünay O (1997) Characterization of Tannery wastewater for pretreatment-selected case studies. Water Sci. Technol. 36(2-3): 217-223.

Bangladesh INSPIRED (2013) Technical Report: Leather Sector Includes a Value Chain Analysis and Proposed Action Plans, pp. 3.

Chaudry MA, Ahmad S, Malik MT (1998) Supported liquid membrane technique applicability for removal of chromium from tannery wastes. Waste Manage 17(14): 211-218

Costa CR, Olivi P (2009) Effect of chloride concentration on the electrochemical treatment of a synthetic tannery wastewater. ElectrochimicaActa 54 (7): 2046-2052.

Dantas TLP, José HJ, Moreira RdeF P M (2003) Fenton and Photo-Fenton oxidation of tannery wastewater. ActaSci-Technol. 25(1): 91-95.

ECR (1997) Environmental conservation rule, Ministry of Environment\& Forest, Government of the People's Republic of Bangladesh. 
Genovese CV, González JF (1998) Solids removal by coagulation from fisheries wastewaters. Water SA 24 (4): 371-372.

Hashem MA, Tomal MSN, Bushra SA (2016) Oxidation-coagulation-filtration processes for the reduction of sulfide from the hair burning liming wastewater in tannery, Journal of Cleaner Production, 127, 339-342

Haydar S, Aziz JA (2009) Coagulation-flocculation studies of tannery wastewater using combination of alum with cationic and anionic polymers. J Hazard Mater 168(2-3): 1035-1040.

Imran Q, Hanif MA, Riaz MS, Noureen S, Ansari TM, Bhatti HN (2012) Coagulation/Flocculation of Tannery Wastewater Using Immobilized Chemical Coagulants. J Appl Res Technol 10(2):79-86.

Islam KMN, Misbahuzzaman K,Majumder AK, Chakrabarty M (2011) Efficiency of different coagulants combination for the treatment of tannery effluents: a case study of Bangladesh. African J Environ SciTechnol 5(6): 409-419.

Juel MAI, Syed SA, Dey TK (2017) Assessment of Kinetic Coefficients for Chrome Tannery Wastewater Treatment by Activated Sludge System, Iranica Journal of Energy and Environment 8(1): 56-60.

Kim S-H, Moon B-H, Leeb H-I (2001) Effects of $\mathrm{pH}$ and dosage on pollutant removal and floc structure during coagulation. Microchem J 68 (2-3):197-203.

Kornhauser C, Wróbel K, Wróbel K, Malacara JM, Nava LE, Gómez L, González R (2002) Possible adverse effects of chromium in occupational exposure of tannery workers. Industrial Health 40: 207-213.

Krishanamoorthi S, Sivakumar V, Saravanan K, Prabhu TVS (2009) Treatment and Reuse of Tannery Waste Water by Embedded System. Modern ApplSci 3(1): 129-134.

Leghouichi E, Laib E, Guerbet M (2009) Evaluation of chromium contamination in water, sediment and vegetation caused by the tannery of Jijel (Algeria): A case study. Environ Monit Assess 153: 111-117.

Owlad M, Aroua MK, Daud WAA, Baroutian S (2009) Removal of Hexavalent ChromiumContaminated Water and Wastewater: A Review. Water Air Soil Pollut 200:59-77.

Peavy HS, Rowe DR, Tchobanoglous G (1985) Environmental Engineering, McGraw-Hill International, International edition 1985, Singapore.

Sabur MA, Rahman MM, Safiullah S (2013) Treatment of tannery effluent by locally available commercial grade lime. J Sci Res 5 (1):143-150.

Sepehr MN, Nasseri S, Assadi MM, Yaghmaian K (2005) Chromium Bioremoval from tannery industries effluent by AspergillusOryzae Iran. J Environ Health SciEng 2(4): 273-279.

Shegani G (2014) Treatment of Tannery Effluents by the Process of Coagulation. Int J Environ Chem Eco GeolGeophyEng 8 (4):240-244.

Song Z, Williams CJ, Edyvean RGJ (2003) Tannery Wastewater Treatment Using an Up flow Anaerobic Fixed Biofilm Reactor (UAFBR). Environ EngSci 20(6):587-599.

Song Z, Williams CJ, Edyvean RGJ (2004) Treatment of tannery wastewater by chemical coagulation. Desalination 164: 249-259.

Tariq SR, Shah MH, Shaheen N, Khalique A, Manzoor S, Jaffar M (2005) Multivariate analysis of selected metals in tannery effluents and related soil. J Hazard Mater 122:17-22.

Van Groenestijn JW, Langerwerf JSA, Lucas M (2002) Reducing environmental emissions in tanneries. J Environ Sci Health A, 37(4): 737-743.

Verma AK, Bhunia P, Dash RR (2012) Supremacy of Magnesium Chloride for decolourisation of textile wastewater: A comparative study on the use of different coagulants.IntJ Environ Sci Develop 3(2): 118-123.

Online Archive Link: https://abc.us.org/ojs/index.php/ei/issue/archive 